\title{
The protective effect of processed cheese against hyperlipidemia in rats
}

\author{
Mohamed H. AвD El-SAlam ${ }^{1 *}$, Doha A. Mohamed ${ }^{2}$ \\ ${ }^{1}$ Dairy Department, National Research Centre, Dokki, Cairo, Egypt \\ ${ }^{2}$ Food Sciences and Nutrition Department, National Research Centre, Dokki, Cairo, Egypt
}

Received 11 September 2008 - Revised 15 January 2009 - Accepted 16 April 2009

Published online 23 June 2009

\begin{abstract}
The purpose of this study was to examine the effects of intake of processed cheeses containing different types of fats on plasma lipid profile and lipid peroxidation using hypercholesterolemic rats as an experimental model. This study included three types of processed cheeses: the first two contained vegetable oils and the third contained milk fat only. Five groups of rats (8 animals each) were fed balanced diet (normal), hypercholesterolemic diet (control), and hypercholesterolemic diet containing one of the tested processed cheeses, respectively, for 8 weeks. The body weight and the food intake were recorded and the gain in body weight and food efficiency ratio were also calculated. Blood analysis was carried out at the end of the experiment for total lipids and cholesterol, low density lipoprotein, high density lipoprotein (HDL), triglycerides, and plasma malondialdehyde. Feeding the different processed cheeses with hypercholesterolemic diet showed variable reductions in the plasma lipids, except for HDL, which was increased as compared to control. The highest and significant reduction was observed in the group that received processed cheese containing milk fat only. Also, this group showed significant reduction in lipid peroxidation. These results suggest that consumption of processed cheeses may improve the markers of cardiovascular diseases, particularly processed cheeses containing milk fat only. Further studies on human subjects are needed to verify the present results and to elucidate the possible mechanisms behind the differential effects on serum cholesterol of cheeses containing different types of fats.
\end{abstract}

processed cheese / rat / hyperlipidemia / hypercholesterolemia / lipid profile / conjugated linoleic acid

\begin{abstract}
摘要 - 再制干酪对高血脂症大鼠的保护作用。本研究探讨了高血脂症大鼠实验模型饲喂不 同类型脂肪的再制干酪对血脂和脂质过氧化的影响。使用三种类型的再制干酪, 前两种使 用植物油, 第三种只使用乳脂肪。五组均衡饮食 (正常组) 的大鼠 (每组 8 只) 和高血脂症饮 食 (对照组), 而高血脂症饮食组分别饲喂 测试干酪 8 周。记录体重和食物的摄入量, 并对 体重和食物的效率比进行了计算。实验结束后大鼠的血液分析包括总血脂、胆固醇、低密 度脂蛋白、高密度脂蛋白、甘油三酯 (Tg) 和丙二醛 (MDA)。结果表明, 饲喂不同再制干 酪的高血脂症大鼠血脂出现不同程度降低, 但高密度脂蛋白增加; 而饲喂只含乳脂肪干酪 的大鼠组血脂和高密度脂蛋白降低的最显著, 同时, 还能显著降低脂质过氧化反应。因 此, 食用再制干酪特别是只含有乳脂肪的再制干酪可改善心血管疾病。有必要进行人体 实验以验证本实验结果，并探讨含有不同类型脂肪的干酪对血清胆固醇可能的影响机制。
\end{abstract}

再制干酪 / 大鼠 / 高脂血症 / 高胆固醇血症 / 脂质特性 / 共轭亚油酸

*Corresponding author (通讯作者): mo_salam38@yahoo.com 
Résumé - Effet protecteur du fromage fondu contre l'hyperlipidémie chez le rat. Le but de cette étude était d'examiner les effets de la consommation de fromages fondus contenant différents types de matière grasse sur le profil lipidique du plasma et la peroxydation des lipides sur le rat hypercholestérolémique comme modèle experimental. L'étude incluait trois types de fromages fondus ; les deux premiers contenaient des huiles végétales et le troisième uniquement de la matière grasse laitière. Cinq groupes de rats (de 8 animaux chacun) ont bénéficié pendant 8 semaines d'un régime alimentaire équilibré (normal), hypercholestérolémique (contrôle) ou hypercholestérolémique contenant un des fromages fondus testés. Le poids et la prise alimentaire ont été relevés et le gain de poids et le ratio d'efficacité alimentaire ont été calculés. À la fin de l'expérimentation, une analyse du sang a été réalisée pour les lipides totaux et le cholestérol, LDL et HDL, les triglycérides et le malondialdéhyde du plasma. L'apport des différents fromages fondus à un régime hypercholestérolémique a montré des réductions variables des lipides du plasma, à l'exception des HDL qui augmentaient comparativement au contrôle. La réduction significative la plus élevée était observée dans le groupe qui recevait le fromage fondu contenant uniquement la matière grasse laitière. Ce groupe présentait également une réduction significative de la peroxydation des lipides. Ces résultats suggèrent que la consommation de fromages fondus peut améliorer les marqueurs de maladie cardiovasculaire, en particulier les fromages fondus contenant uniquement de la matière grasse laitière. Des études complémentaires sur des sujets humains sont nécessaires pour vérifier les présents résultats et pour élucider les mécanismes possibles sous-jacents aux différents effets sur le cholestérol sérique des fromages contenant différents types de matière grasse. fromage fondu / rat / hyperlipidémie / hypercholestérolémie / profil lipidique / acide
linoléique conjugué

\section{INTRODUCTION}

Current dietary guidelines recommend limiting the consumption of foods high in saturated fat and cholesterol to reduce the risk of cardiovascular disease (CVD) [6]. Milk fat is generally recognized to consistently raise plasma cholesterol concentration, especially in hypercholesterolemic subjects $[14,17,30]$. For this reason, consumption of high fat dairy products would be expected to be associated with CVD risk. However, results of epidemiologic surveys, animal experiments, and human dietary studies have been conflicting [27, 28, 36, 38]. This discrepancy may be ascribed to the differences in the atherogenic effects of various dairy products.

Epidemiologic evidence suggests that cheese may be less atherogenic than other high fat dairy products such as butter $[3,29]$. Animal experiment [33] suggested that the fat derived from cheese could offer some significant reduction in CVD risk markers. This was apparent from the lower total and non-HDL-Ch (high density lipoprotein cholesterol) and increased percentage of long chain $\omega-3$ fatty acids in liver triglycerides (TG) of rats fed on cheese diet, as compared with the tallow-based diet [33]. The long chain $\omega-3$ fatty acids are known by their protective effect on the CVD [26]. Recently, a study based on conventional and metabonomic approaches showed that the lowest atherogenicity was obtained with canola cheese diet followed by the dairy fat cheese diet, while the greatest atherogenicity was observed with the butter diet $(P<0.05)$ in hyperlipidemic hamsters [23]. Also, in the controlled dietary study on human subjects $[3,29]$, cheese was less cholesterol increasing than butter at equal fat content. It is possible that other constituents found in a high concentration in cheese may modulate the CVD risk of cheese. Cheeses are rich sources of dairy calcium, which has been reported to decrease fat adsorption [22] and increase fecal fat excretion [2, 4]. Also, conjugated linoleic acid (CLA), butyrate, and sphingolipids 
and metabolites of bacteria involved in cheese ripening were suggested as potential factors in the beneficial effects of cheese on CVD risk [3, 16, 29, 33, 38].

Out of the different cheeses examined, the effect of processed cheese consumption on the CVD risk factors is almost unknown. This group of cheese is made from the blends of natural cheese and other dairy products (e.g. butter and skim milk powder) with emulsifying salts and several food additives and heated at high temperatures.

In Egypt, addition of saturated vegetable oils with similar melting properties to milk fat (e.g. palm, palm kernel, and coconut oils) in processed cheese manufacture is permitted and the products are covered by a separate standard [11]. Vegetable oils represented a significant part of the cheese fat in several processed cheese brands in Egypt [8]. The use of vegetable oils in the replacement of milk fat in processed cheese making may affect the atherogenic properties of the cheese. The type of fat has a more important role in determining the risk of CVD rather than the total amount of fat in the diet $[14,17]$.

The objective of this study was to evaluate the effect of ingestion of processed cheese containing different types of fats on the plasma lipid profile and the lipid peroxidation of hypercholesterolemic rats.

\section{MATERIALS AND METHODS}

\subsection{Cheese}

Three types of processed cheeses were purchased from the local market. Processed cheese Nos. 1 (Veg 1) and 2 (Veg 2) were labeled to contain vegetable oils, while processed cheese No. 3 (MF) contained only milk fat. The fatty acid composition of these cheeses has been reported in a previous study [8]. They had the following fatty acid composition (Tab. I). Veg 1 was characterized by high $\mathrm{C}_{16}, \mathrm{C}_{18}$, and $\mathrm{C}_{18: 2}$ contents, while Veg 2 was characterized by high $C_{12}$ and
Table I. Fatty acid composition of processed cheeses ( $\%$ of total).

\begin{tabular}{|c|c|c|c|}
\hline Compound & Veg 1 & Veg 2 & MF \\
\hline $\mathrm{C}_{4}$ & 0.48 & 0.65 & 3.86 \\
\hline $\mathrm{C}_{6}$ & 0.25 & 0.67 & 2.37 \\
\hline $\mathrm{C}_{8}$ & 0.21 & 3.81 & 1.32 \\
\hline $\mathrm{C}_{10}$ & 0.36 & 3.24 & 2.85 \\
\hline $\mathrm{C}_{10: 1}$ & 0.03 & 0.04 & 0.31 \\
\hline $\mathrm{C}_{12}$ & 1.93 & 34.42 & 3.30 \\
\hline $\mathrm{C}_{14}$ & 2.59 & 11.85 & 10.50 \\
\hline $\mathrm{C}_{14: 1}$ & 0.04 & 0.13 & 0.89 \\
\hline $\mathrm{C}_{15}$ & 0.24 & 0.20 & 1.13 \\
\hline $\mathrm{C}_{16}$ & 40.65 & 13.09 & 29.20 \\
\hline $\mathrm{C}_{16: 1}$ & 0.33 & 0.26 & 1.66 \\
\hline $\mathrm{C}_{17}$ & 0.19 & 0.13 & 0.52 \\
\hline $\mathrm{C}_{18}$ & 5.23 & 13.80 & 10.03 \\
\hline $\operatorname{trans}(9+10+11) \mathrm{C}_{18: 1}$ & 0.45 & 5.60 & 3.53 \\
\hline $\mathrm{C}_{18: 1}$ & 35.43 & 9.83 & 18.63 \\
\hline $\mathrm{C}_{18: 2}$ & 9.32 & 0.80 & 1.13 \\
\hline $\mathrm{C}_{18: 3}$ & 0.19 & 0.06 & 0.83 \\
\hline CLA & 0.18 & 0.15 & 1.31 \\
\hline Others & 1.91 & 1.29 & 6.64 \\
\hline SFA $^{*}$ & 52.13 & 81.86 & 65.08 \\
\hline $\mathrm{C}_{12}+\mathrm{C}_{14}+\mathrm{C}_{16}$ & 45.17 & 59.36 & 43.00 \\
\hline MUFA $^{*}$ & 36.69 & 15.86 & 25.02 \\
\hline PUFA* & 9.69 & 1.01 & 3.27 \\
\hline
\end{tabular}

From reference [8] (reprinted with permission from the Egyptian Society of Dairy Science).

* SFA, saturated fatty acid; MUFA, monounsaturated fatty acid; PUFA, polyunsaturated fatty acid.

$\mathrm{C}_{14}$ contents and MF by high contents of $\mathrm{C}_{4}, \mathrm{C}_{6}, \mathrm{CLA}$, and $\mathrm{C}_{18: 3}$. The type and the percentage of vegetable oil in Veg 1 and 2 were not given in the label, as it is not mandatory in the Egyptian Standard for processed cheeses and spreads containing vegetable oils [11]. As milk fat is the only known fat to contain $\mathrm{C}_{4}$ [41], the approximate milk fat and vegetable oils in cheese fat can be calculated from its $\mathrm{C}_{4}$ content. Accordingly, Veg 1 and 2 contained $\sim 88 \%$ and $83 \%$, respectively, of vegetable oil/total cheese fat.

\subsection{Animals}

Male Albino rats of $103-110 \mathrm{~g}$ body weight were used in this study. Although 
Table II. Composition of different experimental diets $\left(\mathrm{g} \cdot 100 \mathrm{~g}^{-1}\right)^{* *}$.

\begin{tabular}{|c|c|c|c|c|c|}
\hline \multirow[t]{2}{*}{ Ingredients } & \multicolumn{4}{|c|}{ Hypercholesterolemic diets } & \multirow[t]{2}{*}{ Balanced diet } \\
\hline & Veg 1 & Veg 2 & MF & Control & \\
\hline Casein $^{*}$ & 2.6 & 2.9 & 2.6 & 11.6 & 11.6 \\
\hline Corn oil & - & - & - & - & 6.5 \\
\hline Palm oil & - & - & - & 20 & 3.5 \\
\hline Sucrose & 39.1 & 39.1 & 39.1 & 39.1 & 39.1 \\
\hline Starch & 9.4 & 8.7 & 12.9 & 19.5 & 28.8 \\
\hline Salt mix & 1.3 & 1.3 & 1.0 & 3.5 & 3.5 \\
\hline Vitamin mix & 1 & 1 & 1 & 1 & 1 \\
\hline Fiber & - & - & - & - & 1 \\
\hline Cholesterol & 0.3 & 0.3 & 0.3 & 0.3 & - \\
\hline Cheese samples & 41.4 & 41.7 & 38.1 & - & - \\
\hline
\end{tabular}

${ }_{* *}^{*} 11.6 \mathrm{~g} \cdot 100 \mathrm{~g}^{-1}$ casein contained $10 \mathrm{~g}$ protein.

** All diets contained $20 \%$ fat except balanced diet that contained $10 \%$ fat.

rats are not considered as the best model to study the effect of dietary lipids on serum lipoprotein concentration and metabolism, they are widely used in several studies as they generally support observations in human beings $[30,43]$. The animals were kept individually in stainless steel cages in the animal house at room temperature $\left(20 \pm 2{ }^{\circ} \mathrm{C}\right)$ with a 12-h light-dark cycle. The institution's Guidelines for the Care and Use of Laboratory Animals were followed. Diet and water were given ad libitum.

\subsection{Cholesterol}

Analytical grade cholesterol was obtained from Sigma, St. Louis, USA.

\subsection{Chemical analysis of processed cheese types}

All the fresh cheese samples were analyzed for moisture, protein, fat, and ash using standard AOAC procedures [1]. Cheese fat was extracted [18], methyl esters of fatty acids were prepared [19] and analyzed using gas liquid chromatograph
(GLC) (HP 6890 Series (Agilent Technologies, Palo Alto, CA)) [8].

\subsection{Preparation of processed cheese for animal feeding}

Cheese samples were dried in an air oven at $40{ }^{\circ} \mathrm{C}$ and ground before the preparation of different diets.

\subsection{Preparation of diets}

Balanced diet (normal), hypercholesterolemic diet (control) and three hypercholesterolemic diets each containing one type of processed cheese examined were formulated as given in Table II. A high level of cholesterol $(0.3 \%)$ was added to the diet in order to create a stressful dietary model similar to studies in which CLA was protective against atherosclerosis $[32,35]$. The cholesterol brought in by the diet from the added cheese would be higher in the diet containing milk fat compared to Veg $\mathbf{1}$ and $\mathbf{2}$ diets, as vegetable oils do not contain cholesterol. However, the contribution of cheese in the overall cholesterol content of hypercholesterolemic diet is considered small $(<10 \%$ 
of total cholesterol (T-Ch) in the diet) and was not taken into account, as the experiment was intended to test the protective effect of cheese per se. The presence of oxidized cholesterol in the added reagent was not considered similar to all cited studies [32, 35]. In addition, oxidized cholesterol in processed cheeses was usually found only in very small contents [37].

Different diets contained 5\% moisture, $10 \%$ protein, $20 \%$ fat (except the normal balanced diet that contained 10\% fat), 39.1\% sucrose, $1 \%$ vitamin mixture, $3.5 \%$ salt, and completed to $100 \%$ by starch. The salt mixture and the vitamin mixture were prepared according to $[5,25]$, respectively. Oil soluble vitamins were given orally at a dose of $0.1 \mathrm{~mL} / \mathrm{rat}$ per week. The total calories were $482 \mathrm{kcal} \cdot 100 \mathrm{~g}^{-1}$ of experimental diets and $392 \mathrm{kcal} \cdot 100 \mathrm{~g}^{-1}$ in the balanced diet. In all diets, fat energy represented $37.3 \%$ of total dietary energy.

\subsection{Design of experimental study}

Forty rats were divided into five groups (eight rats each). Groups 1-3 received hypercholesterolemic diets containing one of the different processed cheeses, group 4 received hypercholesterolemic diet (control), and group 5 was fed on balanced diet (normal) for 8 weeks. The experimental period of 8 weeks has been chosen in line with the previous studies [12, 20, 33]. During the experiment, body weight and food intake were recorded weekly. At the end of the experiment, the total food intake, body weight gain, and food efficiency ratio were calculated. Blood samples were collected from all the rats at the end of the study, after an overnight fast. Plasma was analyzed colorimetrically using specific kits (Stanbio Laboratory, Boerne, TX, USA) for total lipids [39], T-Ch [42], HDL-Ch [7], low density lipoprotein cholesterol (LDL-Ch) [13], and TG [24]. The HDL$\mathrm{Ch} / \mathrm{T}-\mathrm{Ch}$ ratio was calculated. Plasma malondialdehyde (MDA) was determined
Table III. Average composition of processed cheese samples.

\begin{tabular}{lccr}
\hline Constituents & \multicolumn{3}{c}{$\mathrm{g} \cdot 100 \mathrm{~g}^{-1}$ dry matter } \\
\cline { 2 - 4 } & Veg 1 & Veg 2 & MF \\
\hline Protein & 18.8 & 18.00 & 21.5 \\
Fat & 50.9 & 50.5 & 55.2 \\
Ash & 5.6 & 5.5 & 6.8 \\
Carbohydrates & 24.7 & 26.0 & 16.5 \\
\hline \multirow{2}{*}{ Carbohydrates were calculated by differences. }
\end{tabular}

colorimetrically as a thiobarbituric acid value [34] as an indicator for lipid peroxidation.

\subsection{Statistical analysis}

One-way analysis of variance followed by Duncan's test was applied between the different experimental groups. In all cases, $P<0.05$ was used as the criterion of statistical significance.

\section{RESULTS}

Processed cheese samples demonstrated fat/dry matter content that ranged from $50.47 \%$ in Veg 2 to $55.22 \%$ in MF, while Veg 1 showed $50.89 \%$ fat content.

The proximate composition (\% per dry matter) of cheese samples is shown in Table III. Veg 1 and 2 cheeses had nearly the same gross composition while MF cheese was characterized by higher protein, fat, and ash contents, and lower carbohydrate content than the other two cheeses. This can be attributed to the possible inclusion of high percentages of skim milk powder and/or whey powder in Veg $\mathbf{1}$ and $\mathbf{2}$ as compared to MF. The high carbohydrate content in Veg $\mathbf{1}$ and $\mathbf{2}$ may support this conclusion. Based on the relative butyric acid and CLA contents (Tab. I), the estimated vegetable fat/total cheese fat was about $88 \%$ and $83 \%$ for Veg $\mathbf{1}$ and $\mathbf{2}$, 
Table IV. Nutritional parameters of different experimental groups.

\begin{tabular}{llcccccc}
\hline Groups & & $\begin{array}{c}\text { Initial } \\
\text { body } \\
\text { weight }(\mathrm{g})\end{array}$ & $\begin{array}{c}\text { Final } \\
\text { body } \\
\text { weight }(\mathrm{g})\end{array}$ & $\begin{array}{c}\text { Body } \\
\text { weight } \\
\text { gain }(\mathrm{g})\end{array}$ & $\begin{array}{c}\text { Total } \\
\text { food } \\
\text { intake }(\mathrm{g})\end{array}$ & $\begin{array}{c}\text { Food } \\
\text { intake } \\
\left(\mathrm{g} \cdot d a y^{-1}\right)\end{array}$ & $\begin{array}{c}\text { Food } \\
\text { efficiency } \\
\text { ratio }\end{array}$ \\
\hline Veg 1 & Mean & 108.90 & $174.10^{\mathrm{b}}$ & $65.30^{\mathrm{b}}$ & $574.00^{\mathrm{b}}$ & $10.30^{\mathrm{b}}$ & $0.11^{\mathrm{b}}$ \\
& $\pm \mathrm{SE}$ & 2.14 & 2.94 & 1.63 & 6.85 & 0.12 & 0.01 \\
Veg 2 & Mean & 108.90 & $208.60^{\mathrm{a}}$ & $99.80^{\mathrm{a}}$ & $628.90^{\mathrm{a}}$ & $11.20^{\mathrm{a}}$ & $0.16^{\mathrm{b}}$ \\
& $\pm \mathrm{SE}$ & 1.89 & 2.49 & 2.34 & 7.89 & 0.14 & 0.01 \\
MF & Mean & 108.80 & $218.00^{\mathrm{a}}$ & $109.30^{\mathrm{a}}$ & $647.30^{\mathrm{a}}$ & $11.60^{\mathrm{a}}$ & $0.17^{\mathrm{a}}$ \\
& $\pm \mathrm{SE}$ & 1.59 & 4.99 & 4.31 & 7.07 & 0.13 & 0.01 \\
Control & Mean & 108.90 & $215.30^{\mathrm{a}}$ & $106.50^{\mathrm{a}}$ & $641.80^{\mathrm{a}}$ & $11.50^{\mathrm{a}}$ & $0.17^{\mathrm{a}}$ \\
& $\pm \mathrm{SE}$ & 2.00 & 3.75 & 3.58 & 6.84 & 0.12 & 0.01 \\
\multirow{2}{*}{ Normal } & Mean & 108.40 & $219.10^{\mathrm{a}}$ & $110.80^{\mathrm{a}}$ & $670.80^{\mathrm{a}}$ & $12.00^{\mathrm{a}}$ & $0.17^{\mathrm{a}}$ \\
& $\pm \mathrm{SE}$ & 0.82 & 2.08 & 1.74 & 3.29 & 0.06 & 0.01 \\
\hline
\end{tabular}

Data with different superscripts in the same column are significantly different $(P<0.05)$.

respectively, which suggests that smaller quantities of natural cheese were used in their formulations than in MF cheese.

Nutritional parameters of different experimental groups are shown in Table IV. There was no difference in the final body weight, body weight gain, and food intake, except in rats fed on hypercholesterolemic diet containing processed cheese 1 , which showed a significant reduction in all nutritional parameters $(P<0.05)$. Food efficiency ratio was reduced significantly in rats fed on hypercholesterolemic diets containing processed Veg $\mathbf{1}$ and $\mathbf{2}$ when compared with the control group. The nonsignificant changes in nutritional parameters especially food intake and final body weight in rats fed on hypercholesterolemic diet containing processed MF cheese probably reflect the palatability of the processed cheese used in this study, while processed Veg 1 seems to reduce diet palatability, as shown from all determined nutritional parameters.

The control rats fed the hypercholesterolemic diet showed a significant increase in the plasma levels of total lipids $(+40 \%$, $P<0.05)$, T-Ch $(+20 \%, P<0.05)$, LDLCh $(+14 \%, P<0.05)$, and TG $(+17 \%$,
$P<0.05)$ (Tab. V), which was accompanied by a decrease in the HDL-Ch and the HDL-Ch/T-Ch ratios $(-31 \%$ and $-85 \%$, respectively, $P<0.05$ ) (Tab. V). Plasma level of MDA (Tab. V) as an indicator of lipid peroxidation was increased significantly $(+61 \%, P<0.05)$ in hypercholesterolemic rats when compared with normal rats fed on balanced diet.

Inclusion of processed cheeses in hypercholesterolemic diets improved variably the biochemical parameters of plasma (Tab. V), as compared to the control. Generally, Veg 1 showed the lowest improvement in the plasma lipid profile, while MF showed the highest improvement in the plasma lipid profile and peroxidation in hypercholesterolemic rats. Statistical analysis showed that the MF was the only processed cheese that significantly improved the lipid profile and peroxidation of hypercholesterolemic rats.

\section{DISCUSSION}

Feeding rats a diet rich in cholesterol evoked an increase in risk factors for atherosclerosis and CVD such as dyslipidemia 
Table V. Biochemical parameters of different experimental groups.

\begin{tabular}{|c|c|c|c|c|c|c|c|c|}
\hline Groups & & $\begin{array}{l}\text { T. lipids } \\
\left(\mathrm{g} \cdot \mathrm{dL}^{-1}\right)\end{array}$ & $\begin{array}{c}\mathrm{T}-\mathrm{Ch} \\
\left(\mathrm{mg} \cdot \mathrm{dL}^{-1}\right)\end{array}$ & $\begin{array}{l}\mathrm{HDL}-\mathrm{Ch} \\
\left(\mathrm{mg} \cdot \mathrm{dL}^{-1)}\right.\end{array}$ & $\begin{array}{l}\text { LDL-Ch } \\
\left(\mathrm{mg} \cdot \mathrm{dL}^{-1}\right)\end{array}$ & $\begin{array}{l}\mathrm{HDL}-\mathrm{Ch} / \\
\text { T-Ch ratio }\end{array}$ & $\begin{array}{c}\mathrm{TG} \\
\left(\mathrm{mg} \cdot \mathrm{dL}^{-1}\right)\end{array}$ & $\begin{array}{c}\text { MDA } \\
\left(\mathrm{nmol} \cdot \mathrm{mL}^{-1}\right)\end{array}$ \\
\hline \multirow[t]{3}{*}{ Veg 1} & Mean & $0.52^{\mathrm{a}}$ & $108.00^{\mathrm{a}}$ & $32.30^{\mathrm{a}}$ & $27.1^{\mathrm{a}}$ & $0.30^{\mathrm{a}}$ & $109.30^{\mathrm{a}}$ & $8.30^{\mathrm{a}}$ \\
\hline & $\pm \mathrm{SE}$ & 0.01 & 2.09 & 0.33 & 0.43 & 0.05 & 2.48 & 0.21 \\
\hline & $\%$ change & -7 & -3 & -0.4 & -2 & 3 & -0.4 & 4 \\
\hline \multirow[t]{3}{*}{ Veg 2} & Mean & $0.59^{\mathrm{a}}$ & $106.30^{\mathrm{a}}$ & $33.00^{\mathrm{a}}$ & $26.7^{\mathrm{a}}$ & $0.30^{\mathrm{a}}$ & $104.40^{\mathrm{a}}$ & $7.70^{\mathrm{a}}$ \\
\hline & $\pm \mathrm{SE}$ & 0.01 & 1.16 & 0.65 & 0.5 & 0.01 & 2.40 & 0.13 \\
\hline & $\%$ change & -6 & -5 & 2 & -4 & 7 & -5 & 4 \\
\hline \multirow[t]{3}{*}{ MF } & Mean & $0.55^{\mathrm{b}}$ & $100.60^{\mathrm{b}}$ & $40.00^{\mathrm{b}}$ & $25.1^{\mathrm{b}}$ & $0.40^{\mathrm{b}}$ & $97.50^{\mathrm{b}}$ & $5.90^{\mathrm{b}}$ \\
\hline & $\pm \mathrm{SE}$ & 0.01 & 1.18 & 0.53 & 0.33 & 0.01 & 1.42 & 0.25 \\
\hline & $\%$ change & -16 & -10 & 23 & -9 & 37 & -11 & -26 \\
\hline \multirow[t]{3}{*}{ Control } & Mean & $0.61^{\mathrm{a}}$ & $111.70^{\mathrm{a}}$ & $32.50^{\mathrm{a}}$ & $27.7^{\mathrm{a}}$ & $0.30^{\mathrm{a}}$ & $109.70^{\mathrm{a}}$ & $7.90^{\mathrm{a}}$ \\
\hline & $\pm \mathrm{SE}$ & 0.01 & 1.95 & 0.54 & 0.44 & 0.01 & 3.04 & 0.19 \\
\hline & $\%$ change & 40 & 20 & -31 & 14 & -43 & 17 & 61 \\
\hline \multirow[t]{2}{*}{ Normal } & Mean & $0.44^{\mathrm{c}}$ & $92.80^{\mathrm{c}}$ & $47.20^{\mathrm{c}}$ & $24.4^{\mathrm{c}}$ & $0.51^{\mathrm{c}}$ & $93.70^{\mathrm{c}}$ & $4.90^{\mathrm{c}}$ \\
\hline & $\pm \mathrm{SE}$ & 0.02 & 1.49 & 0.93 & 0.62 & 0.01 & 1.30 & 0.26 \\
\hline
\end{tabular}

Data with different superscripts in the same column are significantly different $(P<0.05)$.

(high TG, total- and LDL-Ch, and low HDL-Ch) and lipid peroxidation (increased MDA levels). This general profile elicited by an unhealthy dietary pattern (atherogenic diet) was reverted variably when different processed cheeses were included in the diet. Consumption of processed cheese-based diets reduced the total plasma lipids, T-Ch, LDL-Ch, and TG and increased the HDL$\mathrm{Ch} / \mathrm{T}-\mathrm{Ch}$ ratio as compared to the control group receiving hypercholesterolemic diet. These effects were more pronounced in an MF-based diet. Several factors may be responsible for the observed differences in the protective effect of processed cheeses against hyperlipidemia in rats. Higher percentage of natural cheeses was probably used in the production of MF cheese compared to the other two cheeses as apparent from the low carbohydrate (mainly lactose) content in this type of cheese (Tab. II). Also, Veg 1 and 2 were estimated to contain 88\% and $83 \%$ vegetable oils in the total cheese fat, respectively. This means that the natural cheeses would account for about $20 \%$ solids in these two types of cheeses, as compared to $>50 \%$ natural cheeses in $\mathbf{M F}$ (without vegetable oils). Previous report [28, 33] showed that the consumption of natural cheeses had a beneficial effect on CVD risk markers (High TG, total- and LDL-Ch, and low HDL-Ch). Based on that the atherogenic characteristics of processed cheeses are probably related to the level of natural cheese used in the blend; the more natural cheese the less atherogenic is the obtained processed cheese. $\mathrm{C}_{12}, \mathrm{C}_{14}$, and $\mathrm{C}_{16}$ are considered as the most potent saturated fatty acids in raising LDL-Ch in various animal models [30]. The sum concentrations of these acids in Veg 1 and 2 were $45.17 \%$ and $59.36 \%$, being higher than their content in milk fat; namely $43.0 \%$ (Tab. I) which may explain the higher atherogenic effect of Veg 1 and 2 than MF. The carbohydrate contents of the different diets may have no effect on the serum lipid profile. Starch and lactose are the carbohydrates found in the experimental diets. Tholstrup [38] found that the addition of lactose to cheese to match this component in milk did not affect the low LDL-Ch in subjects consuming 
cheese as compared to those consuming whole milk. Also, neither raw nor retrograded resistant starch had any significant effect on the serum lipids of healthy subjects [15].

Martin et al. [23] indicated that the determinal effect of a high saturated intake on atherogenesis can be modulated by accompanying compounds or the physico-chemical nature of the food matrix. This may be considered as another factor responsible for the observed differences in the atherogenic effects of the different processed cheeses tested.

A more specific factor that may be responsible for the observed differences in the protective effect of processed in hyperlipidemia lies in its content of CLA. Based on the fatty acid composition of the tested cheeses (Tab. I), diet containing MF was calculated to contain $0.26 \%$ CLA, while those containing Veg 1 and 2 were calculated to contain $0.036 \%$ and $0.03 \%$ CLA, respectively. These differences may explain the observed differences in the blood lipid profile of rats receiving diets containing the different cheeses. CLA has been considered anticarcinogenic and antiatherosclerotic at concentrations of $0.5-1 \%$ in the diet of animals [33]. Valeille et al. [40] suggested that the atherogenic potential of milk fat can be greatly reduced in products with a naturally high content of $c_{9} t_{11}$ content. Although CLA isomers have different physiological effects, ingestion of $c_{9} t_{11}$ and/or $\mathrm{t}_{10} \mathrm{c}_{12}$ CLA isomers decreased plasma lipid concentrations (cholesterol and $\mathrm{TG}$ ) in Wistar rats [12]. Nicolosi et al. [31] reported that CLA $(0.06-1.11 \%)$ fed to hamsters along with high dietary cholesterol $(0.12 \%)$ reduced plasma T-Ch, especially atherogenic apolipoprotein B and TG. Lee et al. [21] fed rabbits a $0.1 \%$ cholesterol diet and $0.5 \mathrm{~g} \cdot \mathrm{d}^{-1}$ CLA and found significantly lower plasma, total- and LDL-Ch, and TG after three months. Furthermore, the LDL/ HDL and the T-Ch/HDL-Ch ratios were reduced in the CLA-fed rabbits, which were associated with decreased atherosclerosis. When CLA was fed concurrently with cholesterol, plasma and liver cholesterol were reduced up to $40 \%$, which was attributed to reduced cholesterol absorption [35]. This may support the probable role of the CLA content of processed cheese in modulating the plasma lipid profile in hypercholesterolemic rats.

Increased oxidative stress appears to play an important role in the chronic inflammatory responses to hypercholesterolemia [9]. Although the precise mechanism of atherogenesis is not fully understood, oxidative modification of LDL is considered to be an essential process in the activation of the inflammatory pathway leading to atherosclerosis [10]. MDA is one of the lipid peroxidation products. Therefore, measurement of MDA is taken as an index of lipid peroxidation and oxidative stress. Inclusion of processed cheeses in the hypercholesterolemic diet decreased the MDA level in blood serum of rats as compared to the control. Processed cheeses may have a direct and an indirect effect in this respect. As for the direct effect, processed cheeses are subjected to heat treatment during processing, which increases their free $\mathrm{SH}$ groups and antioxidant activity depending on the heating conditions and percentage of proteins. In addition, natural antioxidants, such as vitamin $\mathrm{E}$ of processed cheeses, may add to the antioxidant activity of processed cheeses. The LDL lowering effect of processed cheese may be considered as an indirect effect responsible for the observed reduction in the MDA level in rats receiving hypercholesterolemic diet containing processed cheeses. However, cheese containing milk fat only decreased markedly the MDA values of rats on hypercholesterolemic diets in comparison to cheeses containing vegetable oils. This suggests that the low LDL in this group of rats is the main factor for the observed low lipid peroxidation. Also, the relatively high CLA content of processed cheese containing milk fat only may explain 
the reduced lipid peroxidation in the group of rats receiving this diet. Kyeong et al. [20] reported that dietary CLA reduced lipid peroxidation by increasing oxidative stability in rats, being in support with the present finding. It is suggested that other markers of oxidative stress (e.g. 4-hydroxyalkenals and isoprostanes) are to be performed in future studies in order to validate the effect of CLA on serum lipid peroxidation.

\section{CONCLUSION}

The intake of processed cheeses containing different types of fats improved variably the cardiovascular marker in hypercholesterolemic rats with normal processed cheese (containing milk fat only), which was more effective than cheeses containing vegetable oils. This study suggests that consumption of processed cheese containing milk fat may be beneficial in reducing the risk of CVDs. Further studies on human subjects are needed to verify the present results and to elucidate the possible mechanisms behind the differential effects on serum cholesterol of cheeses containing different types of fats.

\section{REFERENCES}

[1] AOAC, Official Methods of Analysis of the Association of Official Agriculture Chemists, 12th edn., Washington DC, USA, 1995.

[2] Bendsen N.T., Hother A.-L., Jensen S.K., Lorenzen J.K., Asturp A., Effect of dairy calcium on fecal fat excretion: a randomized crossover trial, Int. J. Obes. 32 (2008) 1816 1824.

[3] Biong A.S., Muller H., Seljeflot I., Veierod M.B., Pederson J.I., A comparison of the effects of cheese and butter on serum lipids, haemostatic variables and homocysteine, $\mathrm{Br}$. J. Nutr. 92 (2004) 791-797.

[4] Boon N., Hul G.B.J., Stegen H.C.H., Sluijsmans W.F.M., Valle C., Langin D., Viguerie N., Saris W.H.M., An intervention study of the effect of calcium intake on faecal fat excretion, energy metabolism and adipose tissue mRNA expression of lipid metabolism related proteins, Int. J. Obes. 31 (2007) 1704-1712.

[5] Briggs G.M., Williams M.A., A new mineral mixture for experimental rat diets and evaluation of other mineral mixtures, Fed. Proc. 22 (1963) 261-266.

[6] British Heart Foundation, Cut the saturated fat, 2004, http://www.bhf.org.uk.

[7] Burstein M., Scholnick H.R., Morfin R., Rapid method for the isolation of lipoproteins from human serum by precipitation with polyanions, J. Lipid Res. 11 (1970) 583-595.

[8] Calvo M.V., Juarez M., Fontecha J., El-Aasar M., Naguib M., Abd El-Salam M.H., Effect of milk fat replacement with vegetable oils on fatty acids composition and conjugated linoleic acid content of market Egyptian processed cheeses, Egypt. J. Dairy Sci. 35 (2007) 97-107.

[9] Catapano A.L., Maggi F.M., Tragni E., Low density lipoprotein oxidation, antioxidants, and atherosclerosis, Curr. Opin. Cardiol. 5 (2000) 355-363.

[10] Colin D.F., Tillmann C., 12/15-lipoxygenase, oxidative modification of LDL and atherogenesis, Trends Cardiovasc. Med. 11 (2001) 116-124.

[11] Egyptian Standards Organization, Processed Cheese and Spreads Containing Vegetable Oils, Standard No. 999, 2002.

[12] Faulconnier Y., Arnal M.-A., Mirand P.P., Chardigny J.-M., Chilliard Y., Isomers of conjugated linoleic acid decrease plasma lipids and stimulate adipose tissue lipogenesis without changing adipose weight in post-prandial adult sedentary or trained Wistar rat, J. Nutr. Biochem. 15 (2004) 741-748.

[13] Gerard T., Gerald A.L., Process and reagents for the selective separation of low density lipoprotein (LDL) and for the quantification of their components, EP 0076211, 1983.

[14] Hegsted D.M., Ausman L.M., Johnson J.A., Dallal G.E., Dietary fat and serum lipids: an evaluation of the experimental data, Am. J. Clin. Nutr. 7 (1993) 875-883.

[15] Heijnen M.L., Van Amelsvoort J.M., Deurenberg P., Beynen A.C., Neither raw nor retrograded resistant starch lowers 
fasting serum cholesterol concentrations in healthy normolipidemic subjects, Am. J. Clin. Nutr. 64 (1996) 312-318.

[16] Houston D.K., Driver K.E., Bush A.J., Kritchevsky S.B., The association between cheese consumption and cardiovascular risk factors among adults, J. Hum. Nutr. Diet. 21 (2008) 129-140.

[17] Hu F.B., Manson J.E., Willett W.C., Types of dietary fat and risk of coronary heart disease: a critical review, J. Am. Coll. Nutr. 20 (2001) 5-19.

[18] ISO-IDF, Milk and Milk Products - Extraction Methods for Lipids and Liposoluble Compounds, Standard No. 14156, International Dairy Federation, Brussels, Belgium, 2001.

[19] ISO-IDF, Milk Fat - Preparation of Fatty Acids Methyl Esters, Standard No. 15884, International Dairy Federation, Brussels, Belgium, 2002.

[20] Kim H.-K., Kim S.-R., Ahn J.-Y., Cho I.-J., Yoon C.-S., Ha T.-Y., Dietary conjugated linoleic acid reduces lipid peroxidation by increasing oxidative stability in rats, J. Nutr. Sci. Vitaminol. 51 (2005) 8-15.

[21] Lee K.N., Kritchevsky D., Pariza M.W., Conjugated linoleic acid and atherosclerosis in rabbits, Atherosclerosis 108 (1994) 1925.

[22] Lorenzen J.K., Nielsen S., Holst J.J., Tetens I., Rehfeld J.F., Astrup A., Effect of dairy calcium or supplementary calcium intake on postprandial fat metabolism appetite and subsequent energy intake, J. Am. Clin. Nutr. 85 (2007) 678-687.

[23] Martin J.C., Canlet C., Delplanque B., Agnani G., Lairon D., Gottardi G., Bencharif K., Gripois S., Thaminy A., Paris A., (1)H NMR metabonomics can differentiate the early atherogenic effect of dairy products in hyperlipidemic hamsters, Atherosclerosis (2009), doi: 10.1016/j.atherosclerosis.2009.01.040.

[24] Megraw R., Dunn D., Biggs H., Manual and continuous flow colorimetry of triacylglycerols by a fully enzymic method, Clin. Chem. 25 (1979) 273-278.

[25] Morcos S.R., The effect of protein value of the diet on the neurological manifestations produced in rats by $\beta$-immodipropionitrile, Br. J. Nutr. 21 (1967) 269-274.

[26] Mori T.A., Beilin L.J., Long chain Omega 3 fatty acids blood lipids and cardiovascular risk reduction, Curr. Opin. Lipidol. 12 (2001) 11-17.

[27] Ness A.R., Davey-Smith G., Hart C., Milk, coronary heart disease and mortality, J. Epidemiol. Community Health 55 (2001) 379-382.

[28] Nestel P.J., Effect of dairy fats within different foods on plasma lipids, J. Am. Coll. Nutr. 27 (2008) 735S-740S.

[29] Nestel P.J., Chronopulos A., Chun M., Dairy fat in cheese raises LDL cholesterol less than that in butter in mildly hypercholesterolaemic subjects, Eur. J. Clin. Nutr. 59 (2005) 1059-1063.

[30] Nicolosi R.J., Dietary fat saturation effects on low-density-lipoprotein concentrations and metabolism in various animal models, Am. J. Clin. Nutr. 65 (Suppl.) (1997) 1617S-1627S.

[31] Nicolosi R.J., Rogers E.J., Kritchevsky D., Scimeca J.A., Huth P.J., Dietary conjugated linoleic acid reduces plasma lipoproteins and early aortic atherosclerosis in hypercholesterolemic hamsters, Artery 22 (1997) 266277.

[32] Pariza M.W., Park Y., Cook M.E., Conjugated linoleic acid and the control of cancer and obesity, Toxicol. Sci. 52 (1999) 107110.

[33] Roupas P., Royle P., Descamps R., Scherer B., McIntosh G., The impact of cheese consumption on markers of cardiovascular risk in rats, Int. Dairy J. 16 (2006) 243-251.

[34] Satoh K., Serum lipid peroxide in cerebrovascular disorders determined by a new colorimetric method, Clin. Chim. Acta 90 (1978) 37-43.

[35] Sher J., Pronczuk A., Hajri T., Hayes K., Dietary conjugated linoleic acid lowers plasma cholesterol during cholesterol supplementation, but accentuates the atherogenic lipid profile during the acute phase response in hamsters, J. Nutr. 133 (2003) 456-460.

[36] Sjogren P., Rosell M., Skoglund-Andersson C., Zdravkovic S., Vessby B., De Faire U., Hamsten A., Hellenius M.-L., Fisher R., Milk derived fatty acids are associated with a more favourable LDL particle size distribution in healthy men, J. Nutr. 134 (2004) 1729-1735.

[37] Sieber R., Oxidized cholesterol in milk and dairy products, Int. Dairy J. 15 (2005) 191206. 
[38] Tholstrup T., Dairy products and cardiovascular disease, Curr. Opin. Lipidol. 17 (2006) $1-10$.

[39] Toro G., Ackerman P.G., Practical Clinical Chemistry, 1st edn., Little, Brown and Company, Boston, USA, 1975.

[40] Valeille K., Férézou J., Parquet M., Amsler G., Gripois D., Quignard-Boulangé A., Martin J.C., The natural concentration of the conjugated linoleic acid cis-9, trans-11 in milk fat has antiatherogenic effects in hyperlipidemic hamsters, J. Nutr. 136 (2006) 1305-1310.
[41] Walstra P., Jenness R., Dairy Chemistry and Physics, John Wiley \& Sons Inc., New York, USA, 1984.

[42] Watson D., A simple method for the determination of serum cholesterol, Clin. Chem. Acta 5 (1960) 637-643.

[43] Zulet M.A., Barber A., Garcin H., Higueret A., Martinez J.A., Alterations in carbohydrate and lipid metabolism induced by a diet rich in coconut oil and cholesterol in rat model, J. Am. Coll. Nutr. 18 (1999) 36-42. 